TPBIO (Jurnal Pendidikan Biologi)
Vol. 5, No. I, April 2020, I - I / / e-ISSN 2540-802X
http://jurnal.stkippersada.ac.id/jurnal/index.php/JBIO/index

\title{
Pengembangan asesmen kompetensi pedagogik pada mahasiswa calon guru biologi
}

Check for updates

\section{Ina Setiawati*, Anna Fitri Hindriana}

Pendidikan Biologi, Universitas Kuningan, Jl. Cut Nyak Dhien No.36A, Kuningan (455I3), JA-BAR, Indonesia ${ }^{*}$ Korespondensi penulis: inabiologi@gmail.com

\section{Informasi artikel}

Riwayat artikel:

Dikirim 07 November 2019

Direvisi I3 Desember 2019

Diterima I3 Februari 2020

Dipublikasi 07 April 2020

\section{Kata kunci:}

Asesmen, kompetensi, pedagogik, mahasiswa calon guru

\section{ABSTRAK}

Instumen penilaian pedagogik belum maksimal digunakan di FKIP Universitas Kuningan. Penelitian ini bertujuan mengembangkan asesmen pedagogik yang dapat mengukur kompetensi pedagogik pada mahasiswa calon guru biologi dengan menggunakan rubrik penilaian. Metode penelitian adalah research and development. Pengumpulan data dilakukan dengan menggunakan lembar validasi tim expert, lembar kuesioner respon mahasiswa. Hasil uji validasi tim ahli didapat rata-rata skor 4,I8 (sangat valid), hasil uji kelayakan didapat nilai sebesar $83 \%$ (sangat layak). Hasil Pengujian validitas instrument diperoleh nilai KMO pada asesmen kemampuan merancang pembelajaran sebesar $0,55>0,5$, asesmen melaksanakan pembelajaran $0,50>0,5$, asesmen mengevaluasi $0,74>0,5$ dan secara keseluruhan nilai $\mathrm{KMO}>0,5$. Hasil penilaian kompetensi pedagogik mahasiswa ujicoba I menunjukkan $80 \%$ berada level kompeten secara parsial dalam merancang pembelajaran, $56 \%$ berada pada level kompeten dalam melaksanakan simulasi pembelajaran, $32 \%$ berada pada level kompeten parsial dalam melakukan evaluasi pembelajaran, sehingga dapat disimpulkan valid dan layak untuk digunakan.
Keywords:

Assessment, competency, pedagogical, pre-service teacher

\section{ABSTRACT}

Development of pedagogical competency assessment in pre-service teacher of biology. Pedagogical assessment instruments have not been used maximally at FKIP Universitas Kuningan. This research aims to develop pedagogical assessments that can measure pedagogical competencies in Biology pre-service teacher by using an assessment rubrik. The research method was research and development. Data collection was carried out using expert team validation sheets, student response questionnaire sheets. The results of the expert team validation test obtained an average score is 4.18 (very valid), the feasibility test results obtained a value is $83 \%$ (very feasible). The instrument testing the validity results value in the assessment of the ability to design learning is $0.55>0.5$, the assessment to carty out learning is $0.50>0.5$, the evaluation evaluates is $0.74>0.5$, overall value is $K M O>0.5$. The pedagogical competency evaluation results of pilot I showed students were partially competent in designing learning is $80 \%$, students were at the competent level in carrying out learning simulations is $56 \%$, students were partial competence in evaluating learning is $32 \%$, so that are concluded valid and can using.

(C) 2020 Setiawati \& Hindriana This is an open access article under the CC-BY-SA license

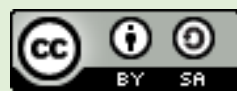

Sitasi: Setiawati, I., \& Hindriana, A.F. (2020). Pengembangan asesmen kompetensi pedagogik pada mahasiswa calon guru biologi. JPBIO (Jurnal Pendidikan Biologi), 5(I), I-II. DOI: I0.31932/jpbio.v5iI.53I 


\section{PENDAHULUAN}

Mahasiswa calon guru di fakultas keguruan merupakan tonggak kemajuan pendidikan di masa depan. Mahasiswa calon guru merupakan calon pendidik yang memiliki peran strategis dalam proses pembelajaran, terutama dalam mengembangkan kualitas sumber daya manusia (Hakim, 2017). Peningkatan kualitas mahasiswa calon guru penting untuk dilakukan, agar dapat menghasilkan generasi penerus bangsa yang berkualitas. Salah satu cara untuk meningkatkan kualitas mahasiswa calon guru adalah dengan meningkatkan kompetensi mahasiswa calon guru sebagai pendidik di masa depan (Arifa, 2019). Kegiatan melatih kompetensi mahasiswa calon guru adalah salah satu aspek terpenting dari kurikulum fakultas keguruan, karena fakultas keguruan harus mempersiapkan mahasiswa calon guru untuk menjadi guru yang berkualitas di masa depan. Manfaat pelatihan (praktek mengajar) tersebut tidak hanya mengembangkan keterampilan profesional, namun juga keterampilan komunikasi, manajemen pengelolaan kelas, kepercayaan diri dalam mengajar, serta meningkatkan kemampuan mencari sumber daya pengajaran (Ulla, 2016).

Salah satu kompetensi yang dapat dilatihkan kepada mahasiswa calon guru di fakultas keguruan adalah kompetensi pedagogik. Kompetensi pedagogik merupakan kompetensi penting yang harus dikuasai oleh mahasiswa calon guru, karena kompetensi pedagogik ini adalah kemampuan awal yang menentukan penyelenggaran pembelajaran untuk mencapai tujuan pembelajaran (Anif, 2018; Anif et al., 2019). Menurut Undang-Undang No. I4 Tahun 2005 tentang Guru dan Dosen menjelaskan bahwa kompetensi pedagogik merupakan seperangkat pengetahuan, keterampilan, dan perilaku yang harus dimiliki, dihayati dan dikuasai oleh guru atau dosen dalam melaksanakan tugas keprofesionalannya. Pedagogik merupakan suatu studi tentang seni dan ilmu mengajar (Arends, 2008). Kompetensi pedagogik yang perlu dikuasai mahasiswa calon guru dalam mengelola pembelajaran adalah perancangan, pelaksanaan pembelajaran, evaluasi hasil belajar, serta pengembangan peserta didik sesuai potensi yang dimilikinya. kompetensi pedagogik adalah kemampuan guru dalam mengelola pembelajaran berdasarkan pendekatan dengan memperhatikan pemahaman peserta didik, perencanaan dan pelaksanaan pembelajaran, evaluasi hasil pembelajaran dan pengembangan potensi peserta didik (Emiliasari, 2018). Kompetensi pedagogik merupakan salah satu faktor yang mempengaruhi kualitas pendidikan. Kompetensi pedagogis umumnya melibatkan dua aspek yakni pengetahuan dan keterampilan (Ningtiyas, 2018)

Kompetensi pedagogik mahasiswa calon guru di FKIP Universitas Kuningan biasa dilatih melalui kegiatan praktek mengajar kelas kecil (micro teaching). Ketika mahasiswa calon guru berinteraksi dengan teman-temannya dalam pembelajaran micro teaching, mahasiswa calon guru akan belajar satu sama lainnya. Proses tersebut akan membantu membangun kompetensi pedagogik diantaranya kompetensi merancang pembelajaran, melaksanakan pembelajaran, mengevaluasi pembelajaran. Hasil dari penilaian pada kegiatan micro teaching ini akan memberikan informasi ketercapaian kompetensi pedagogik mahasiswa. Harapannya mahasiswa mampu mengetahui hasil evaluasi capaian komptensi secara deskriptif, sehingga mahasiswa akan mampu mengevaluasi serta meningkatkan capaian keterampilan professional mahasiswa sendiri. (Donnelly, 2007; Nurlaelah, 2017). Namun, faktanya capaian kompetensi pedagogik mahasiswa di FKIP Universitas Kuningan hanya tergambarkan dengan rentang nilai yang belum mampu mendeskripsikan capaian kompetensi pedagogik mahasiswa secara berkelanjutan. Peneliti juga menemukan masalah bahwa pelatihan kompetensi pedagogik yang telah dilaksanakan di FKIP selama ini melalui praktek mengajar belum sesuai dengan kebutuhan mahasiswa calon guru. Mahasiswa membutuhkan pelatihan kompetensi yang berkelanjutan dengan komunikasi aktif antara peserta pelatihan. Pelatihan berkelanjutan tentunya membutuhkan instrument yang dapat mengukur kompetensi secara berkelanjutan pula.

Berdasarkan hasil observasi di FKIP Universitas Kuningan menyatakan bahwa instrumen yang mengukur kompetensi pedagogik mahasiswa calon guru dalam melaksanakan praktek mengajar masih belum jelas, karena tidak disertai rubrik yang tepat. Kompetensi pedagogik dapat dilatihkan pada mahasiswa calon guru sebelum mahasiswa bekerja sebagai guru di sekolah, melalui pelatihan mengajar di micro teaching ataupun praktek di sekolah. Namun permasalahannya, belum adanya instrument yang dapat memfasilitasi dalam melakukan evaluasi kompetensi pedagogik tersebut, sehingga proses pembelajaran masih sekedar mengingat dan memahami serta terfokus pada hafalan materi (Hidayati et al., 2019). Harapannya suatu instrument evaluasi itu mampu mengukur serta mengevaluasi, sehingga umpan balik dari kegiatan penilaian tersebut mampu meningkatkan kualitas menuju yang lebih baik. Kualitas kemampuan mahasiswa calon guru yang perlu ditingkatkan diantaranya kemampuan merancang, melaksanakan dan mengevaluasi pembelajaran. Kemampuan merancang, melaksanakan pembelajaran dan mengevaluasi merupakan tuntutan kompetensi guru yang tertuang dalam Undang-undang Sisdiknas nomor 20 tahun 2007 yang menyatakan bahwa seorang guru harus memiliki empat kompetensi diantaranya kompetensi pedagogik, professional, sosial, dan kepribadian. 
Kompetensi mahasiswa calon guru dalam merancang dan melaksanakan pembelajaran dan mengevaluasi pembelajaran sangat penting untuk bekal mahasiswa kelak menjadi seorang guru biologi. Oleh karena itu, diperlukan asesmen yang dapat digunakan untuk menilai kompetensi pedagogik mahasiswa calon guru. Asesmen ini dapat digunakan oleh dosen, teman sejawat (peer asesmen) ataupun mahasiswa sendiri (self asesmen) yang akan memudahkan penilai baik dosen ataupun mahasiswa calon guru untuk mengidentifikasi kelebihan dan kekurangan kompetensi pedagogik yang harus dicapai oleh mahasiswa calon guru. Penggunaan asesmen yang berkelanjutan akan membantu mahasiswa calon guru untuk merefleksi ketercapaian kompetensi pedagogik. Asesmen pedagogik merupakan suatu kerangka kerja yang menggambarkan dan melaporkan level kinerja mengajar mahasiswa calon guru, asesmen ini membantu mengumpulkan informasi berdasarkan hasil observasi praktek mengajar yang konsisten dengan mengukur variable-variabel yang jelas. Penggunaan asesmen pedagogik dalam praktek mengajar juga dikembangkan Brown (2008) dengan menggunakan rubrik yang menilai pengalaman mengajar professional mahasiswa calon guru. Rubrik tersebut membantu mengontrol kualitas mengajar mahasiswa calon guru dengan tepat disertai level-level kompetensi yang harus dicapai. Rubrik penilaian mengajar professional membantu mahasiswa calon guru memahami teori serta menerapkan teori kedalam praktek mengajar (Brown, 2008).

Seperti halnya yang dikembangakan Brown, asesmen pedagogik ini merupakan suatu instrument yang baru karena dilengkapi dengan rubrik penskoran yang dapat memfasilitasi mahasiswa calon guru untuk dapat mengajar dengan baik. Menurut Hindriana (2018) rubrik berisi dimensi yang berisi kriteria-kriteria yang harus dicapai oleh mahasiswa calon guru, serta skala yang menjelaskan tentang perolehan kinerja yang harus dicapai. Dengan demikian, akan memudahkan dosen dan mahasiswa calon guru untuk mengevaluasi kompetensi yang sudah dicapai sehingga bisa memperbaiki penampilan mengajar.

\section{METODE PENELITIAN \\ Rancangan Penelitian}

Metode penelitian yang digunakan dalam penelitian ini adalah Research and Development (R\&D). Tahapan metode penelitian, yaitu model ADDIE meliputi analysis, design, development, implementation, dan e valuation yang dikembangkan oleh Reiser dan Mollenda (Molenda, 2003).

\section{Populasi dan Sampel Penelitian}

Populasi dalam penelitian ini adalah seluruh mahasiswa calon guru biologi Universitas Kuningan. Sampel penelitian adalah I kelas mahasiswa calon guru biologi sebanyak 28 mahasiswa. Adapun teknik pengambilan sampel adalah purposive sample.

\section{Instrumen Penelitian}

Instrumen yang digunakan dalam mengembangkan assesmen kompetensi pedagogik ini adalah lembar validasi tim expert, angket respon mahasiswa calon guru, rubrik penilaian kompetensi pedagogik. Instrumen lembar validasi diisi oleh 3 orang expert yang mengukur aspek yang terdiri dari aspek pedagogik, aspek content, aspek kebahasaan, aspek desain dan penyajian. Instrumen lembar angket dibagikan kepada responden (mahasiswa calon guru dan dosen), yang memuat pernyataan tentang kepraktisan asesmen pedagogik, kebermanfaatan asesmen pedagogik, kemudahan penggunaan asesmen kompetensi pedagogik. Rubrik penilaian kompetensi pedagogik yang digunakan pada tahap uji pertama coba pertama menilai kompetensi pedagogik mahasiswa calon guru meliputi; kemampuan merancang pembelajaran, melaksanakan pembelajaran dan mengevaluasi.

\section{Prosedur Penelitian}

Tahapan penelitian meliputi analysis, design, development, implementation, dan evaluation. Tahap analisis terdiri dari dua tahap yaitu tahap analisis kinerja dan tahap analisis kebutuhan. Setelah diketahui kebutuhannya, maka lanjut ke tahap kedua yaitu desain. Desain yang dibuat diharapkan mampu menjawab apakah program asesmen yang akan didesain dapat mengatasi masalah pada tahap analisis. Komponen desain asesmen kompetensi guru biologi yang dikembangkan diantaranya: a) task (meliputi: merancang pembelajaran, melaksanakan proses pembelajaran, dan melaksanakan evaluasi), b) rubrik penilaian kompetensi guru biologi.

Tahap ketiga adalah tahap pengembangan, dalam penelitian ini peneliti akan mengembangkan instrument asesmen kompetensi mahasiswa calon guru. Tahap keempat adalah tahap implementasi yaitu penerapan atau uji coba asesmen kompetensi guru pada mahasiswa calon guru. Tahap kelima yaitu tahap evaluasi asesmen 
kompetensi guru apakah telah memenuhi kualitas suatu produk yang valid, praktis dan mempunyai efek potensial. Adapun kelima tahapan ADDIE dapat dilihat pada Gambar I.

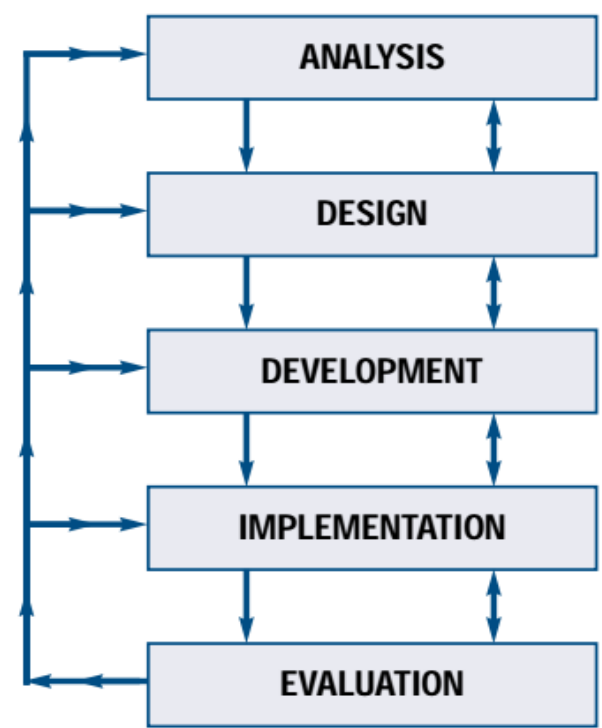

Gambar I. Model pengembangan ADDIE (Mollenda, 2003)

\section{Teknik Analisis Data}

Teknik analisis data dalam penelitian ini meliputi: (a) analisis data untuk validasi ahli dengan kriteria validitas pada Tabel I; (b) menentukan kesimpulan dari setiap aspek yang divalidasi, ditetapkan tingkat kelayakan dan revisi produk seperti pada Tabel 2; (c) analisis angket dalam bentuk presentase frekuensi distribusi pada Tabel 3; dan (d) analisis kompetensi pedagogik dengan konversi nilai pedagogik pada Tabel 4.

Tabel I. Klasifikasi validasi oleh validator

\begin{tabular}{ll}
\hline Rentang skor & Klasifikasi validasi \\
\hline $4,2 \mathrm{I}-5,0$ & Sangat valid \\
\hline 3,4I $-4,20$ & valid \\
\hline 2,6I $-3,40$ & Cukup valid \\
\hline I,8I $-2,60$ & Kurang valid \\
\hline I,00 - I,80 & Tidak valid \\
\hline
\end{tabular}

Tabel 2. Klasifikasi tingkat kelayakan

\begin{tabular}{cl}
\hline Persentase & Kriteria \\
\hline $0 \%-20 \%$ & Sangat lemah \\
\hline $21 \%-40 \%$ & Lemah \\
\hline $41 \%-60 \%$ & Cukup \\
\hline $61 \%-80 \%$ & Baik atau layak \\
\hline $81 \%-100 \%$ & Sangat layak \\
\hline
\end{tabular}

Tabel 3. Interpretasi data

\begin{tabular}{ll}
\hline Persentase & Interpretasi \\
\hline $65 \%-100 \%$ & Baik \\
\hline $35 \%-65 \%$ & Cukup \\
\hline $20 \%-35 \%$ & Kurang \\
\hline Kurang dari $20 \%$ & Tidak baik \\
\hline
\end{tabular}


Tabel 4. Konversi nilai pedagogik

\begin{tabular}{lll}
\hline Skor rata-rata & Nilai & Level kompetensi pedagogik \\
\hline $3,6-4,0$ & $90-100$ & Unggul. \\
\hline $2,6-3,5$ & $75-89$ & Kompeten, \\
\hline $2,0-2,5$ & $50-74$ & Kompeten secara parsial \\
\hline $1,0-1,9$ & $25-49$ & Perlu Perbaikan \\
\hline
\end{tabular}

\section{HASIL PENELITIAN}

Data untuk mengetahui tingkat kelayakan dan validasi diperoleh dari 3 orang validator. Penilaian kelayakan terdiri dari 3 komponen penilaian diantaranya; kelayakan isi, penyajian dan bahasa yang masingmasing komponen memiliki indicator. Selain kelayakan, data validator pun digunakan untuk menganalisis tingkat validitas yaitu validitas isi dan validitas konstruk. Adapun data hasil validasi oleh validaor dan kelayakan asesmen pedagogik dapat dilihat pada Tabel 5.

Tabel 5. Hasil rekapitulasi hasil validasi asesmen oleh 3 validator

\begin{tabular}{llccccl}
\hline No & Aspek & Validator I & Validator 2 & Validator 3 & Skor rata-rata & Kriteria \\
\hline $\mathrm{I}$ & Isi & 4,50 & 4,42 & 4,00 & $4,3 \mathrm{I}$ & Sangat valid \\
\hline 2 & Konstruk & $4, \mathrm{I} 7$ & 4,33 & 3,83 & $4, \mathrm{II}$ & Sangat valid \\
\hline 3 & Bahasa & 4,20 & 4,40 & 3,40 & 4,00 & Sangat valid \\
\hline & Rata-rata skor validator & $\mathbf{4 , 2 9}$ & $\mathbf{4 , 3 8}$ & $\mathbf{3 , 7 4}$ & $\mathbf{4 , I 4}$ & Sangat valid \\
\hline
\end{tabular}

Berdasarkan Tabel 5. menunjukkan bahwa rata-rata skor validasi dari 3 orang validator diantaranya; 4,29 (valid), 4,38 (valid), dan 3,74 (valid), jika dirata-ratakan skor yang diperoleh adalah 4,I4 yang menjelaskan tingkat validitas sangat valid. Berdasarkan hasil penilaian dari 3 validator mengenai tingkat validitas asesmen tersebut dinyatakan valid untuk digunakan dalam menilai kompetensi pedagogik mahasiswa calon guru. adapun hasil analisis tingkat kelayakan untuk setiap komponen penilaian oleh validator disajikan pada Gambar 2.

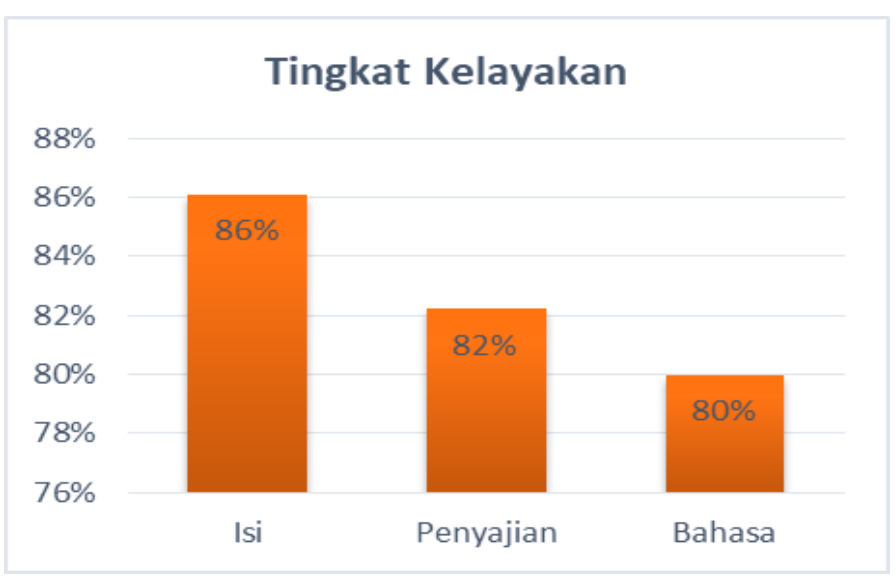

Gambar 2. Penilaian kelayakan

Berdasarkan Gambar 2. memperlihatkan bahwa hasil penilaian kelayakan yang dilakukan oleh 3 tim expert, didapatkan rata-rata persentase tingkat kelayakan sebesar 82,6\% (sangat layak). Pada komponen kelayakan isi didapatkan persentase penilaian sebesar $86 \%$ dengan kategori sangat layak, persentase penilaian kelayakan penyajian sebesar $82 \%$ dengan kategori sangat layak, dan persentase kelayakan bahasa sebesar $80 \%$ dengan kategori layak. Berdasarkan hasil penilaian semua komponen pada asesmen pedagogik mahasiswa calon guru biologi, maka dapat dijelaskan asesmen tersebut dinyatakan layak untuk digunakan dalam menilai kompetensi mahasiswa calon guru pada mata kuliah strategi pembelajaran dan perencanaan pembelajaran.

Sebelum asesmen autentik digunakan untuk menilai kompetensi mahasiswa calon guru (merencanakan, melaksanakan, mengevaluasi). Maka terlebih dahulu dilakukan uji validitas dan reliabilitas dari instrument penelitian ini menggunakan SPSS. Adapun hasil dari validitas dan reliabilitas disajikan pada Tabel 6, Tabel 7 , dan Tabel 8. 
Tabel 6. Hasil uji validitas menggunakan $\mathrm{KMO}$ and bartlett's test pada asesmen merencanakan

\begin{tabular}{llr} 
Kaiser-Meyer-Olkin Measure of Sampling Adequacy. & $.55 \mathrm{I}$ \\
\hline Bartlett's Test of Sphericity & Approx. Chi-Square & $\mathrm{I} 69.524$ \\
\cline { 2 - 3 } & $d f$ & 66 \\
\cline { 2 - 3 } & Sig. & .000 \\
\hline
\end{tabular}

Tabel 7. Hasil uji validitas menggunakan $\mathrm{KMO}$ and bartlett's test pada asesmen melaksanakan pembelajaran

\begin{tabular}{llr}
\hline Kaiser-Meyer-Olkin Measure of Sampling Adequacy. & \multicolumn{1}{c}{.500} \\
\hline Bartlett's Test of Sphericity & Approx. Chi-Square & 223.428 \\
\cline { 2 - 3 } & Sig. & 105 \\
\cline { 2 - 3 } & & .000 \\
\hline
\end{tabular}

Tabel 8. Hasil uji validitas menggunakan $\mathrm{KMO}$ and bartlett's test pada asesmen mengevaluasi

\begin{tabular}{|c|c|c|}
\hline \multicolumn{2}{|c|}{ Kaiser-Meyer-Olkin Measure of Sampling Adequacy. } & .742 \\
\hline \multirow[t]{3}{*}{ Bartlett's Test of Sphericity } & Approx. Chi-Square & 30.834 \\
\hline & $d f$ & 6 \\
\hline & Sig. & .000 \\
\hline
\end{tabular}

Berdasarkan Tabel 6. sampai Tabel 8. terlihat hasil output analisis faktor di atas terhadap data instrumen diperoleh nilai Kaiser-Meyer-Olkin Measure of Sampling Adequacy (KMO MSA) sebesar > 0.5, yang berarti dapat dinyatakan valid. Selanjutnya untuk reliabiltas terlihat pada Tabel 9. Berdasarkan hasil pada Tabel 9 menunjukkan nilai koefisien alpha cronbach di atas 0,7. Hasil analisis data menunjukkan bahwa semua instrument bersifat reliable.

Tabel 9. Hasil uji reliabiltas

\begin{tabular}{cclr}
\hline Test & Designing & \multicolumn{1}{c}{ Assessment } \\
& Carty Out Learning & Evaluate \\
\hline Cronbach"s Alpha & 0.777 & 0.886 & 0.803 \\
\hline
\end{tabular}

Kompetensi pedagogik mahasiswa calon guru biologi yang diukur pada tahap uji coba pertama menggunakan rubrik asesmen pedagogik yang sedang dikembangkan. Adapun aspek yang diukur menggunakan rubrik ini adalah kemampuan merancang pembelajaran, melaksanakan pembelajaran dan mengevaluasi. Adapun hasil pengukuran kompetensi pedagogik dilihat pada Gambar 3.

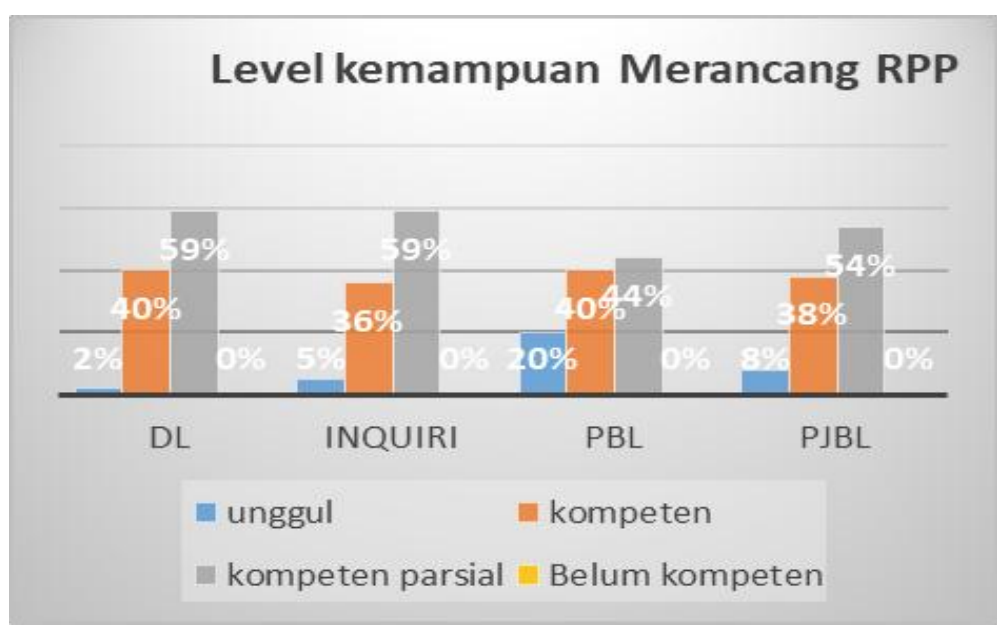

Gambar 3. Level kemampuan merancang RPP

Berdasarkan Gambar 3. menjelaskan tentang level kemampuan merancang RPP menggunakan 4 model kurtilas yaitu Discovery Learning (DL), Inquiry, Problem Based Learning (PBL) dan Project Based Learning do) I0.31932/jpbio.v5iI.53I Setiawati \& Hindriana 
(PiBL). Level kemampuan merancang RPP mahasiswa calon guru biologi sebagian besar berada pada level kompeten secara parsial dalam merancang pembelajaran menggunakan model kurikulum 2013. Namun sekitar 20\% mahasiswa berada pada level unggul dalam membuat RPP PBL.

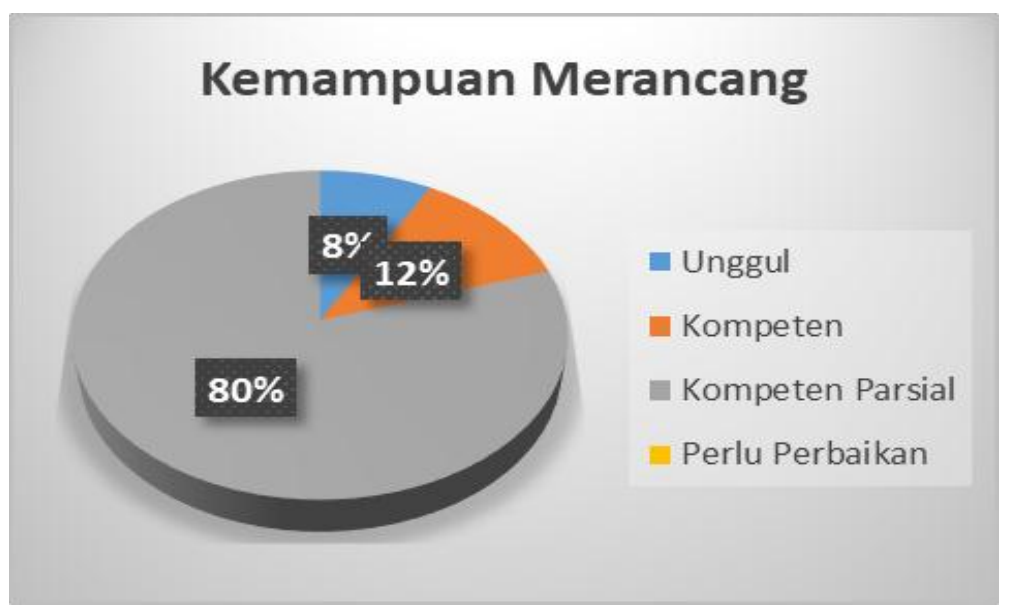

Gambar 4. Level kemampuan merancang

Berdasarkan Gambar 4. menjelaskan tentang level kemampuan merancang RPP secara umum, level kemampuan merancang RPP mahasiswa calon guru biologi secara umum $80 \%$ berada pada level kompeten secara parsial, sebanyak 12\% mahasiswa berada pada level kompeten, dan sebanyak $8 \%$ mahasiswa berada pada level unggul. Merancang pembelajaran mahasiswa penting dilakukan untuk menentukan tujuan pembelajaran sehingga mahasiswa mampu melaksanakan pembelajaran dan menilai hasil belajarnya (Hasse et al., 20I4).

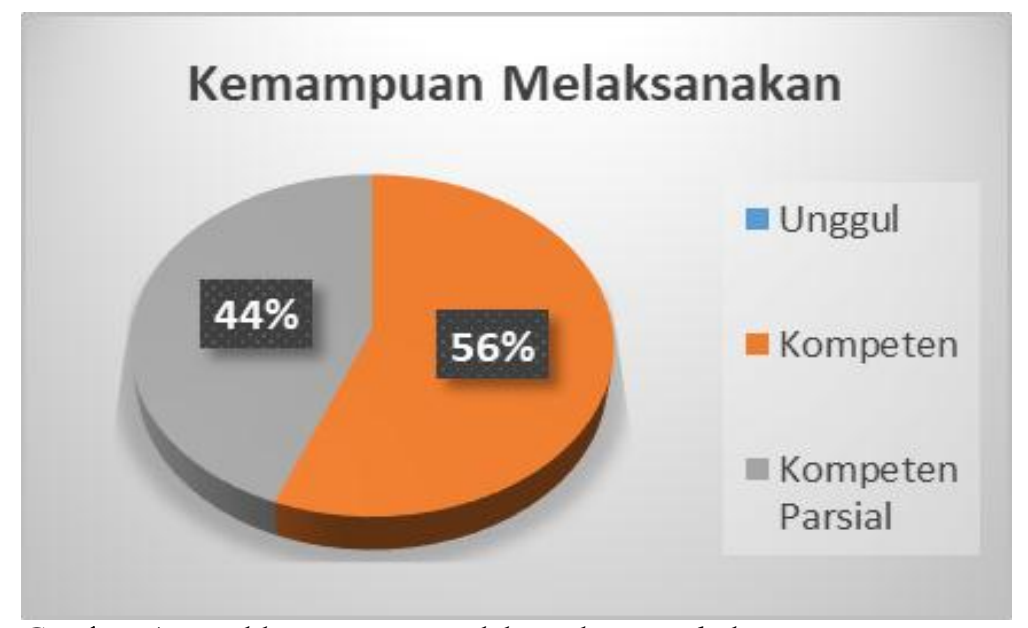

Gambar 5. Level kemampuan melaksanakan pembelajaran

Berdasarkan Gambar 5. menjelaskan tentang level kemampuan dalam melaksanakan pembelajaran mahasiswa sebanyak 56\% mahasiswa berada pada level kompeten dalam melaksanakan simulasi pembelajaran di kelas dan sebanyak $44 \%$ mahasiswa berada pada level kompeten secara parsial dalam melaksanakan simulasi pembelajaran di kelas.

Berdasarkan Gambar 6. menjelaskan tentang level kemampuan mengevaluasi, sebanyak 44\% berada pada level kompeten, sebanyak $24 \%$ berada pada level unggul, dan sebanyak 32\% berada pada level kompeten parsial dalam melakukan evaluasi pembelajaran.

Angket sebanyak 28 angket disebarkan pada mahasiswa calon guru, namun hanya 20 angket yang kembali. Dari 20 angket tersebut mahasiswa calon guru memberikan respon positif (baik) terhadap penggunaan asesmen pedagogik. Respon mahaiswa calon guru terhadap asesmen ini, didapat persentase rata-rata sebesar $84 \%$ kategori baik, sebanyak 96\% mahasiswa calon guru menyatakan bahwa asesmen pedagogik ini sangat bermakna dan penting untuk digunakan, sebanyak $83 \%$ mahasiswa setuju bahwa asesmen pedagogik memiliki kebermanfaatan bagi mahasiswa, dan sebanyak $73 \%$ mahasiswa menyatakan mudah menggunakan asesmen pedagogik. Adapun hasil respon mahasiswa calon guru tertuang pada Gambar 7.

dol10.31932/jpbio.v5iI.53I Setiawati \& Hindriana




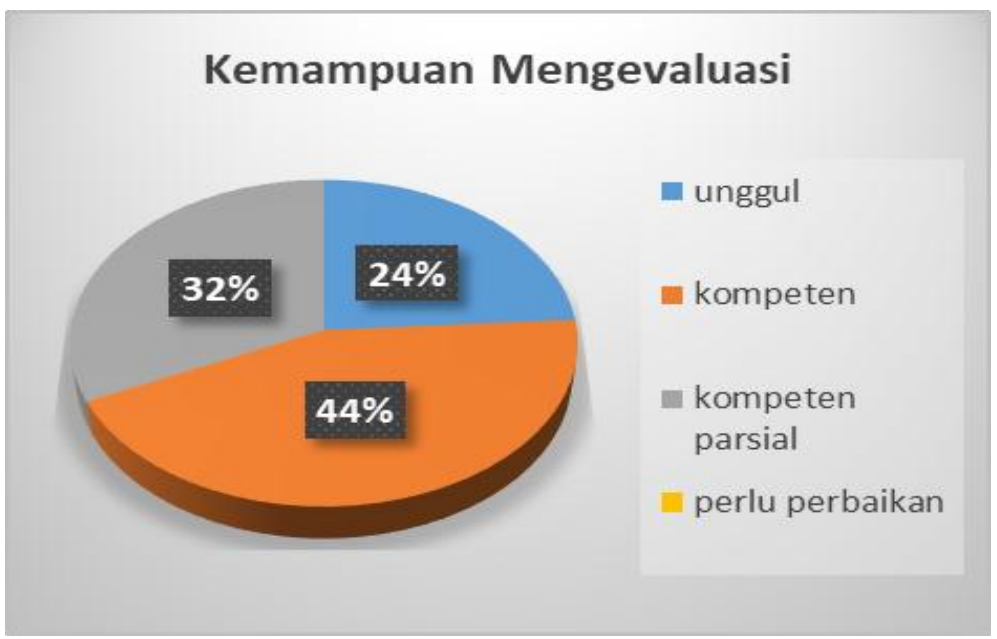

Gambar 6. Level kemampuan mengevaluasi

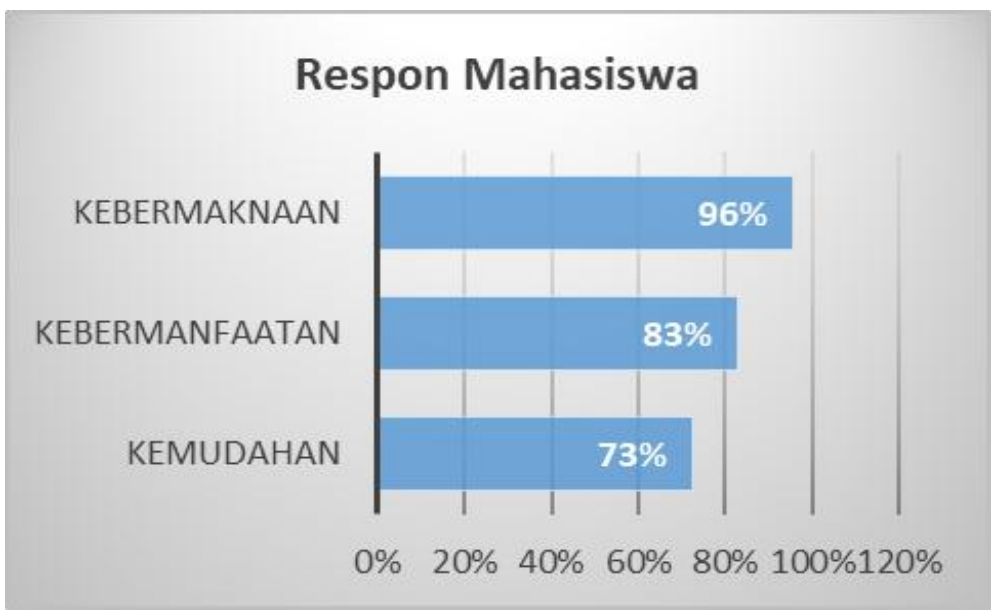

Gambar 7. Respon mahasiswa calon guru terhadap penggunaan asesmen pedagogik

\section{PEMBAHASAN}

Produk asesmen pedagogik hasil pengembangan merupakan seperangkat alat yang digunakan untuk mengukur kompetensi pedagogik mahasiswa calon guru biologi di FKIP Universitas Kuningan. Asesmen pedagogik ini terdiri dari task dan rubrik yang mengukur aspek diantaranya: kompetensi merancang pembelajaran, melaksanakan pembelajaran serta mengevaluasi pembelajaran. Produk ahkir berupa panduan penilaian yang bisa digunakan pada pembelajarn micro teaching ataupun kegiatan praktek mengajar di Sekolah Mitra. Berdasarkan hasil penilaian dari 3 validator mengenai tingkat validitas asesmen pedagogik tersebut dinyatakan valid untuk digunakan dalam menilai kompetensi pedagogik mahasiswa calon guru. Hasil revisi yang dilakukan peneliti berdasarkan rekomendasi dari tim expert, diantaranya; I) harus memperbaiki deskripsi level/skala pada rubrik, pada level unggul dan kompeten ada beberapa deskripsi dimensi yang hampir sama, tak terlihat jelas perbedaannya; 2) deskripsi level atau skala dibuat lebih singkat agar lebih mudah aplikasi di lapangan; 3) harus diperbaiki penulisan, banyak kesalahan penulisan dan spasi yang rapat, terdapat kriteria antar level yang belum jelas batasannya; 4) beberapa indikator atau kriteria tiap level agar dibuat poin yang jelas, tidak berupa paragraf; 5) harus diperbaiki banyak kata yang salah penulisan. Pengembangan panduan asesmen pedagogik ini disesuaikan dengan komponen-komponen yang perlu dikuasai oleh mahasiswa calon guru untuk melatih kompetensi pedagogik mahasiswa.

Asesmen kompetensi pedagogik ini bertujuan untuk menilai kompetensi mahasiswa calon guru biologi yang meliputi tiga aspek yang dinilai diantaranya; merencanakan, melaksanakan serta mengevaluasi. Ada \& Azisah (2016) menemukan bahwa kompetensi pedagogik guru berkontribusi terhadap efektivitas pengajaran. Kontribusi ini dilihat dari bagaimana guru dapat mengorganisasi pembelajaran dari mulai mengatur rencana pengajaran, proses pengajaran dan pembelajaran, serta penilaian. Asesmen kompetensi pedagogik membantu mahasiswa calon guru melatih ketiga aspek kompetensi pedagogik. Asesmen ini disertai dengan rubrik penilaian yang membantu

dolio.31932/jpbio.v5iI.53I Setiawati \& Hindriana


memberikan deskripsi yang jelas dari setiap level yang harus dicapai oleh mahasiswa calon guru. Hasil penelitian Brown (2008) menjelaskan bahwa rubrik telah berhasil dalam mengklarifikasi harapan dan mengartikulasikan pengembangan mahasiswa calon guru, mempermudah memperbaiki kekurangan ataupun keterabatasan dari penampilan mahasiswa alon guru.

Hasil penelitian Tang \& Chow (2006) menjelasakan bahwa penggunaan kerangka penilaian di Hong Kong digunakan dalam pengalaman lapangan membantu dan mendukung umpan balik kepada mahasiswa calon guru. Umpan balik tersebut membantu mahasiswa menemukan dan mengklarifikasi kriteria penilaian yang sangat penting yang berorientasi pembelajaran. Potensi rubrik atau kerangka kerja ini memfokuskan umpan balik dari dosen kepada mahasiswa calon guru tentang level kompetensi pedagogik yang harus dicapai mahasiswa calon guru tersebut. Asesmen ini mampu mempromosikan pengembangan pedagogik mahasiswa calon guru (Jordan et al., 2004).

Aspek yang dinilai pada asesmen pedagogik dalam merencanakan pembelajaran meliputi I2 dimensi penilaian, yaitu; komponen RPP, penyusunan indikator, penyusunan tujuan pembelajaran, penyusunan materi ajar, pendahuluan, keseuaian karakteristik masalah dengan model, kesesuaian sintak, media, alokasi waktu, evaluasi, LKS. Dari I2 komponen penilaian tersebut, kompoenen yang mendapat skor yang tertinggi $(3,6)$ pada komponen pemilihan model sesuai dengan materi pelajaran, pada tahap ini pada dasarnya mahasiswa sudah mampu untuk menentukan model atau metode sesuai dengan tuntutan kurikulum, model dan metode yang dipilih sesuai dengan karakteristik materi dan karakteristik siswa. Model atau metode yang dipilih dapat memfasilitasi siswa untuk memahami materi pelajaran serta model dan metode tersebut mudah untuk diterapkan. Berdasarkan Gambar 5 menjelaskan tentang level kemampuan merancang pembelajaran mahasiswa calon guru biologi secara umum $80 \%$ berada pada level kompeten secara parsial, sebanyak I $\%$ mahasiswa berada pada level kompeten, dan sebanyak $8 \%$ mahasiswa berada pada level unggul. Merancang pembelajaran mahasiswa penting untuk menentukan tujuan pembelajaran sehingga mahasiswa akan mampu melaksanakan pembelajaran dan menilai hasil belajarnya (Hasse et al., 20I4).

Aspek yang dinilai pada asesmen pedagogik dalam melaksanakan pembelajaran meliputi I5 dimensi penilaian yaitu; membuka pelajaran, kemampuan memberi pertanyaan, memberikan permasalah, menjelaskan materi, melaksanakan sintak, pendekatan saintifik, penguasaan materi, pengembangan materi, penguasaan metode, interaksi, membimbing, reinforcemet, menilai proses, melakukan evaluasi pembelajaran, menutup pembelajaran. Dimensi penilaian yang tertinggi pada dimensi membuka pelajaran dengan skor 3,48. Keterampilan dalam membuka pelajaran berada pada level kompeten artinya, mahasiswa mampu membuka pelajaran dengan meningkatkan perhatian siswa, dan mampu mempersiapkan kondisi awal pembelajaran dengan baik, lancar sehingga menumbuhkan suasana belajar yang kondusif. Mahasiswa sudah mampu melakukan apersepsi dengan menghubungkan materi yang dipelajari dengan pengalaman atau pengetahuan siswa sebelumnya. Kompetensi pedagogik ini sangat berpengaruh signifikan terhadap proses pembelajaran yang dilakukan oleh mahasiswa calon guru. Mahasiswa calon guru sangat penting untuk belajar bagaimana mengajar apa yang mahasiswa pelajari dari pengalaman mengajar mahasiswa. Para mahasiswa calon guru ini mengaitkan pengetahuan dan keterampilan pedagogis mahasiswa melalui praktek mengajar yang mahasiswa laksanakan di Kampus (Naylor, 2015).

Aspek yang dinilai pada asesmen pedagogik dalam mengevaluasi pembelajaran meliputi 4 dimensi, yaitu teknik penilaian, instrumen penilaian, pengembangan instrumen evaluasi, pelaksanaan evaluasi. Dimensi penilaian yang mendapat skor tertinggi pada dimensi instrument penilaian dengan skor 3,28 yakni level kompeten artinya instrument penilaian yang sudah dibuat mahasiswa sudah teapat mengukur pengetahuan, sikap dan keterampilan. Penyusunan instrument tes yang dibuat sudah sesuai dengan indicator dan tujuan pembelajaran. Pengalaman mengajar mahasiswa calon guru penting untuk diukur menggunakan instrument yang tepat seperti asesmen kompetensi pedagogik. Asesmen kompetensi pedagogik ini dilengkapi dengan rubrik penilaian yang jelas sehingga dapat membantu mahasiswa calon guru untuk melakukan evaluasi terhadap indikator-indikator kompetensi pedagogik yang belum dapat mahasiswa capai. Melalui panduan asesmen ini akan sangat membantu perbaikan kualitas mengajar mahasiswa calon guru.

Sejalan dengan hasil penelitian Ningtiyas (2018) yang menjelaskan bahwa kompetensi pedagogis dari guru matematika yang dilihat dari aspek pengetahuan dipengaruhi oleh pelatihan dan kemampuan pedagogis. Mahasiswa calon guru sama seperti guru yang tentunya memerlukan pelatihan terus menerus dan komunikatif dengan jenis pelatihan mengajar berupa alat pelatihan, model atau metode atau teknik atau strategi pembelajaran, penggunaan teknologi informasi dan media pembelajaran supaya mahasiswa dapat meningkatkan kompetensi pedagogik mahasiswa. Alat pelatihan yang membantu mahasiswa calon guru untuk melatih keterampilan mengajar diantaranya penggunaan panduan asesmen pedagogik ini. 
Produk berupa asesmen kompetensi pedagogik yang dihasilkan dari penelitian ini termasuk sangat valid dan kategori sangat layak, sehingga asesmen kompetensi pedagogik yang dikembangkan diharapkan dapat digunakan untuk menilai kompetensi mahaisswa calon guru biologi. Respon mahasiswa calon guru terhadap asesmen pedagogik dengan pengambilan uji skala kecil sebesar 84\% dengan kategori baik, sehingga dapat dinyatakan respon yang positif. Hal ini sama dengan pendapat dengan Olsson (2013) menjelaskan bahwa pentingnya menilai kompetensi pedagogis guru untuk menilai aspek teoritis, kegiatan pengajaran praktis, efek pembelajaran pada siswa, kolaborasi berbagi pengetahuan dan pengalaman mengajar mahasiswa calon guru. Hasil penilaian dari aspek aspek kompetensi pedagogis tersebut dapat dianalisis dan diberikan komentar bagi perbaikan kualitas pembelajaran yang telah dilaksanakan mahasiswa calon guru berdasarkan pada skala penialain rubrik asesmen kompetensi pedagogis.

\section{SIMPULAN}

Produk asesmen kompetensi pedagogik yang dihasilkan termasuk kategori layak dan valid. Produk ini telah di uji coba tahap pertama sehingga produk ini dapat digunakan sebagai panduan penilaian untuk menilai kompetensi pedagogik mahasiswa calon guru biologi. Hasil validasi oleh validator diperoleh skor rata-rata 4,I4 yang menjelaskan tingkat validitas yang sangat valid dengan tingkat kelayakan sebesar 82,4\% (sangat layak). Respon mahasiswa calon guru tentang asesmen ini dengan pengambilan uji skala kecil sebesar $84 \%$ dengan kategori baik, yang dapat dinyatakan respon mahasiswa positif terhadap penggunaan asesmen tersebut.

\section{REFERENSI}

Ada, J.H., \& Azisah, S. (2016). The contribution of teachers' pedagogical competence toward the effectiveness of teaching of english at mtsn balang-balang. ETERNAL (English, Teaching, Learning, and Research Journal), 2(02), 238-25I. DOI: I0.24252/Eternal.V22.2016.A5

Anif, S. (2018). The effectiveness of a professional competence development model based on an initial competence test on biology teachers: a case study in surakarta. International Journal of Assesment and Evaluation, 25(2), I5-2I. DOI: I0.I8848/2327-7920/CGP/v25i02/I-I2

Anif, S., Sutama, Prayitno, H.J., \& Idrus, N.B.M. (2019). Effectiveness of pedagogical competence: a development model through association of biology teachers' forum. Jurnal pendidikan IPA Indonesia (JPII), 8(I), 22-3I. DOI: I0.I5294/jpii.v8iI.I7I76

Arends, R.I. (2008). Learning to teach: belajar untuk mengajar. Yogyakarta; Pustaka Pelajar.

Arifa, F.N., \& Prayitno, U.S. (2019). Improvement of education quality: pre-service teacher professional education programs in meeting the needs of professional teachers in indonesia. Aspirasi: Jurnal MasalahMasalah Sosial, IO(I), I-I7. DOI: I0.222I2/aspirasi.vIOiI.I229

Brown, N. (2008). Assessment in the professional experience context. Journal of University Teaching \& Learning Practice, 5(I), 88-I0I. https://ro.uow.edu.au/jutlp/vol5/iss I/8

Donnelly. (2007). Perveived impact of peer observation of teaching in higher education. International Journal of Teaching and Learning in Higher Education, I9(2), I I7-I29. https://arrow.tudublin.ie/ltcart/25

Emiliasari, R.N. (2018). An analysis of teachers' pedagogical competence in lesson study of MGMP SMP majalengka. EL TIN Journal, 6(I), 22-33. DOI: I0.22460/eltin.v6iI.p22-33

Hakim, L. (2017). Development strategy of pedagogical competence to improve professionalism of islamic education teacher. Jurnal Pendidikan Islam, 3(2), 207-220. DOI: IO.I5575/jpi.v3i2.I406

Hasse, S., Joachim, C., Bögeholz, S., \& Hammann, M. (2014). Assessing teaching and assessment competences of biology teacher trainees: lessons from item development. International Journal of Education in Mathematics, Science and Technology, 2(3), I9I-205. https:/ files.eric.ed.gov/fulltext/ED548764.pdf

Hidayati, N., Irmawati, F., \& Prayitno, T.A. (2019). Peningkatan keterampilan berpikir kritis mahasiswa biologi melalui multimedia stem education. JPBIO (Jurnal Pendidikan Biologi), 4(2), 84-92. DOI: I0.31932/jpbio.v4i2.536

Hindriana, A.F., \& Setiawati, I. (2018). The development of autentik assessment rubrik for assessing undergraduate students learning and performance. Indonesian Journal of Learning and Instruction, I(I), 2I-28. https://journal.uniku.ac.id/index.php/IJLI/article/viewFile/I279/949

Jordan, P., Phillips, M., \& Brown, E. (2004). We train teachers: why not supervisors and mentors? Physical Educator, 6I(4), 219-22I.

Molenda, M. (2003). In search of the elusive ADDIE model. https://www.danapayne.net/uploads/5/9/7/7/59770463/insearchofelusiveaddie.pdf 
Naylor, D.A., Campbell, E.G., \& Maloney, C. (2015). Learning to teach: what do pre-service teachers report. Australian Journal of Teacher Education, 40 II). DOI: I0.I422I/ajte.20I5v40nI I.7

Ningtiyas, F.A., \& Jailani. (2018). Does teacher's training affect the pedagogical competence of mathematics teachers?. IOP Conf. Series: Journal of Physics: Conf. Series I097 (2018) 0I2106. DOI: I0.1088/I742-6596/I097/I/0I2I06

Nurlaelah, I., Handayani, \& Setiawati, I. (2017). Perkembangan calon guru profesional yang berfokus pada pedagogical content knowledge (pck) pada kelas akademik atas dan akademik bawah di universitas kuningan. Prosiding Seminar Nasional Pendidikan Sain II. Fakultas Biologi Universitas Kristen Satya Wacana.

Olsson, T., \& Roxa, T. (2013). Assessing and rewarding excellent academic teachers for the benefit of an organization. European Journal of Higher Education, 3(I), 40-6I. DOI: I0.1080/2I568235.20I3.77804I

Tang, S.Y.F., \& Chow, A.W.K. (2006). Communicating feedback in teaching practice supervision in a learningoriented field experience assessment framework. Teaching and Teacher Education, 23(7), I066-I085.

Ulla, M.B. (2016). Pre-service teacher training programs in the philippines: the student-teachers practicum teaching experience. EFL Journal, I(3), 235-250. DOI: I0.2I462/eflj.vIi3.23 